\title{
Explaining negotiations in the conciliation committee
}

Fabio Franchino, Università degli Studi di Milano, Milan, Italy Camilla Mariotto, Università degli Studi di Milano, Milan, Italy *

2nd Annual General Conference of the European Political Science Association, 21-23 June 2012 Panel 1306: Inter-institutional Politics in the EU

Abstract: The conciliation committee is the ultimate inter-cameral dispute settlement mechanism of the ordinary (former codecision) legislative procedure of the European Union. Who gets what, and why, in this committee? Are the European Parliament and the Council of Ministers on an equal footing? We argue that the institutional set-up of the committee is bias in favour of the Council. We offer evidence in support of this proposition by estimating, through Wordfish, the similarity between the documents of almost all the dossiers that reached conciliation up to February 2012. This evidence suggests that, in almost seventy percent of times, the final agreement is more similar to the position of the Council. As expected, the Parliament has been more successful after the reform of the Treaty of Amsterdam and in dossiers where the Council decides by qualified majority voting. The Parliament also benefits if the rapporteur comes from a large party because a veto threat is more easily executable. In line with König et al. (2007), the support from the Commission is crucial to parliamentary success. Moreover, when national administrations are more involved in implementation than the Commission, parliamentarians are less accommodating than ministers because they value much more legislative design as control mechanism. Weaker or no support is found for other factors.

\footnotetext{
* Comments we have received at the workshop on 'Decision-making before and after Lisbon' held on 3-4 November 2011 at the University of Leiden have significantly improve this work. We are particularly grateful to the organizers Madeleine Hosli, Amie Kreppel, Běla Plechanovová and Amy Verdun.
} 


\section{Introduction}

In the codecision procedure, now the ordinary legislative procedure of the European Union (EU), the European Parliament and the Council of Ministers employ a conference committee, called the conciliation committee, to settle ultimately the differences that may arise during the adoption of legislation. Who wins in these negotiations, the Council or the Parliament? Are they on an equal footing? What are the factors that determine bargaining success within the committee?

Conference committees are frequently employed in bicameral legislatures to solve outstanding disagreements after a bill has been shuffled back and forth between the two chambers. How these committees operate eventually determines the balance of power between the chambers. As Tsebelis and Money (1997: 118) observe, 'the composition of the conference committee, its decision-making rule, and the set of bicameral restrictions are critically important to the results of bicameral bargaining'.

In most formal models of EU codecision making, the success of a chamber is determined by an arbitrary assumption about the first mover or a random recognition rule (Crombez 1997; Crombez 2001; Tsebelis and Garrett 2000; Steunenberg 1997; Steunenberg 1994). These models are primarily interested in identifying an equilibrium that can be used for inter-procedural comparisons. For Napel and Widgrén (2006) instead, the institutional setup is biased in favour of the Council because its pivotal member is likely to have an higher disagreement value that the respective member in the Parliament. However, the most systematic empirical research on this issue has found that, at least as far as the 1999-2002 period is concerned, these negotiations favour the Parliament (König et al. 2007). Moreover, the Strasbourg assembly is more likely to win over the Council when it is more proximate to the status quo, it is cohesive ${ }^{2}$ and it has the support from the European Commission.

In this work, we will confirm some of these results and take issue with others. We will argue that the conciliation committee is a conference committee by half, in the sense that it is a meeting between a full upper chamber, on the one side, and a delegation of a lower chamber. This, in combination with a unit rule to take decisions, ${ }^{3}$ is likely to bias outcomes in favour of the Council. We offer evidence in support of this proposition by examining almost all the dossiers that reached conciliation from the entry into force of the Maastricht Treaty to February 2012 and estimating, through Slapin and Proksch's (2008; 2009) Wordfish algorithm, the similarity between the committee's joint texts and the documents produced by the two chambers. This evidence suggests that, in almost seventy percent of times, the final agreement is more similar to the position of the Council. As expected, the Parliament has been more successful after the reform of the Treaty of Amsterdam and in dossiers where the Council decides by qualified majority voting. In line with Konig et al. (2007), the support from the Commission is crucial to parliamentary success, but negotiations are also affected by differences among conferees in the availability of ex-ante

\footnotetext{
${ }^{2}$ Low cohesiveness in the Council is also beneficial for the Parliament (König et al. 2007). On the other hand, the brief case study of Tsebelis and Money (1997: 176-9, 204) leans toward greater influence of the Council. Hagemann and Høyland (2010) offer evidence of greater influence of the Council in codecision in the earlier stages of the procedure. They argue that 'the Council has conditional agenda-setting power due to a change in the majority thresholds for adopting legislation from the first to the second reading in the Parliament' (811).

${ }^{3}$ Agreements are approved under closed rule by concurrent majorities in the two chambers (Tsebelis and Money 1997: 176-9).
} 
and ex-post mechanisms employed to oversee execution across implementation paths. Weaker or no support is found for other factors.

\section{Getting to conciliation}

The codecision procedure was introduced with the Treaty of Maastricht in 1993 and later amended by the Treaty of Amsterdam in 1999. With the entry into force of the Treaty of Lisbon in December 2009, it was renamed the ordinary legislative procedure. From only fifteen in 1993, the number of policy areas that are regulated through this procedure has now increased to eighty. The Treaty of Lisbon for instance extended its coverage to several subfields, the most important of which relate to justice and home affairs. Accordingly, the number of bills increased dramatically: from 153 acts adopted in the 1993-9 legislative term to 454 in the 2004-9 term (European Parliament 2009, 8).

According to Article 294 of the Treaty on the Functioning of the European Union, after the first reading by the Parliament of a proposal by the Commission, the Council may either adopt the measure in the wording approved by the Parliament or adopt its own common position if it disagrees with its fellow chamber. Within three months, the Parliament can reject or amend the Council's text by absolute majority. ${ }^{4}$ After further three months, if the Council does not approve the parliamentary amendments, ${ }^{5}$ the presidents of the Council and of the Parliament convene a meeting of the conciliation committee to resolve the remaining differences between the two institutions. In other words, conciliation is necessary when either a qualified majority of or, for amendments rejected by the Commission, the whole Council has failed to approve the amendments inserted by the Parliament after reading its common position.

The conciliation committee is composed of members of the Council and Parliament in equal number. Since the size of the two delegations equals the number of member states, the Council delegation is essentially the Council, where the chief negotiations are normally the deputy permanent representatives chaired by the minister holding the presidency (Rasmussen 2005; Rasmussen 2008; Tsebelis and Money 1997). For the Parliament, its rules of procedure prescribe the composition of its delegation to reflect the whole assembly by political groups. Once the conference of presidents determines the number of members per group, such members are then appointed by the groups themselves. The delegation must include the chair and the rapporteur of the committee responsible for the case at hand as well as three permanent members chosen from among the vice-presidents.

The objective of conciliation is to produce, within six weeks, a joint text supported by a qualified majority of Council delegates and an absolute majority of parliamentary delegates. The Commission takes part to the conciliation negotiations without a right to vote. If agreement is found on a joint text, this document is then voted upon within six weeks, under closed rule and by qualified and simple majority in the Council and Parliament respectively. Unless government changes have incurred in the meanwhile, the Council vote is perfunctory because the composition of this institution and of its conciliation delegation coincides. For the Parliament instead, the combination of closed

\footnotetext{
${ }^{4}$ If the Parliament fails to act, the proposal is deemed to have been adopted in the wording of the Council first reading. The Parliament can also approve this document by simple majority. No act is adopted in case of rejection.

5 The Council approves by qualified majority those amendments that are supported by the Commission, unanimously the unsupported amendments.
} 
rule with simple majority provides the conciliation delegation with a significant agenda setting power vis-à-vis the plenary.

This procedure has changed over time. Before the Treaty of Amsterdam, the Council could not conclude the procedure and adopt a final act after the first parliamentary reading, nor could the Parliament do so at its second reading. The definitive adoption was a Council prerogative. More important for our purposes, if negotiations within the conciliation committee failed, the Council could make a final take-it-or-leave-it offer to the Parliament, which had to muster an absolute majority to halt irrefutably the proposed measure. This last procedural step strengthened, at least in principle, the negotiating hand of the Council (Garrett 1995; Garrett and Tsebelis 1996), but the adoption of a rule of procedure, stating that the parliamentary leadership would table a motion to reject in such circumstance, has presumably limited the Council's potential gains (Hix 2002; Kasack 2004).

A second, less noted, procedural change was the modification of the voting rule in the Council. The Treaty of Maastricht, for instance, specified that measures in the fields of culture as well as the multiannual framework programme in research and technological development were to be adopted following the codecision procedure, but the Council will have to act unanimously. The Council's bargaining hand was presumably stronger in these cases as it could credibly threaten rejection if just a single minister was not happy with the proposal at hand. Qualified majority voting was extended to the framework programme by the Treaty of Amsterdam and to cultural policy by the Treaty of Lisbon.

Table 1 illustrates the frequency with which the conciliation committee has been used. During the fourth and fifth parliamentary term, this intra-cameral dispute settlement mechanism has been employed once every five Commission's proposals. Even allowing for learning and adaptation, this indicates significant inter-institutional conflict. The Treaty of Amsterdam, that made early agreements possible, did not seem to ease up tensions, at least in the first five years. On the other hand, there has been a significant drop in the employment of the committee over the last two legislative terms. This could indicate better working of the mechanisms of inter-institutional cooperation. The lower incidence is also a product of the extension of the ordinary legislative procedure to the majority of EU policy areas, thus inflating the denominator. In sum, conciliation appears to becoming now a proper mechanism to settle disputes, which is used only occasionally.

\section{< TABLE 1 APPROX HERE >}

\section{Conciliation bargaining}

\section{Disagreement value}

Under which conditions should we expect actors to be more or less accommodating when they sit at the negotiating table of the conciliation committee? In case of symmetry between two bargainers, the Nash cooperative solution is driven by the best alternative to a negotiated agreement (Dixit and Skeath 1999, 523-9). The same is true in a noncooperative setting of alternating offers, such as the Rubinstein model (1982), if negotiators attach different values to the disagreement. The value to carry on bargaining increases in one's disagreement value and decreases in the opponent's disagreement value (McCarty and Meirowitz 2007, 285-6). The utility that actors attach to the status quo drives the solutions of spatial models of codecision bargaining as well (Crombez 1997; Crombez 2001; Garrett 1995; Garrett and Tsebelis 1996; Tsebelis and Garrett 2000; Steunenberg 1997; Steunenberg 1994). More specifically, Napel and Widgrén (2006) model the negotiations within the conciliation committee and predict the Council to be significantly 
more influential than the Parliament. The source of this power resides on the fact that, under symmetric preference distributions, the Council pivotal member under qualified majority voting is likely to attach a higher value to the status quo (i.e. be more conservative) that the median voter in the Parliament.

Unfortunately, corroborating evidence is hard to come by. Extending and replicating the work of Thomson et al. (2006), Thomson (2011) finds that a model based on Nash bargaining solution which assumes that the disagreement outcome is equally and highly undesirable for all bargaining actors has greater explanatory power than a similar model with a reference point (or status quo). In other words, including an estimate of the utility associated with failure worsens the predictive power of a model of EU decision-making. Closer to our interest, results appear contradictory. On the one hand, Costello and Thomson (2011) confirm that being closer to the status quo does not enhance the chances of success of the Parliament in codecision. On the other hand, König et al. (2007) find that proximity to the status quo allow a chamber to exert greater influence in conciliation negotiations. We have reasons to doubt this latter result however. These scholars have employed a variable that takes the value of 1 if the Parliament is located closer to the status quo, -1 if it is located closer to the Council, and zero if no information was available. Accordingly, zero means that the two institutions attach the same value to the status quo. Missing data have therefore been treated as highly informative. The impossibility to locate the status quo - the majority of observations in this study - has been considered as univocally indicating that Council and Parliament attach the same value to the disagreement outcome. We are not sure whether this is the best method to treat missing information, especially given the availability of maximum likelihood or multiple imputation approaches (Allison 2001).

How can we explain these results? For Achen (2006: 102), the (negative) utility associated with the reference point underestimates the cost of disagreement. Besides measurement, there are analytical and observational reasons as well. Since legislative bargaining has significant opportunity costs, a resource-constrained and risk-averse proposer has an incentive to initiate only bills on which she is reasonably certain that the majority of legislators values more than the status quo. In an information rich environment, this estimation should not be too difficult. We therefore tend to observe mostly proposals where the cost of disagreement is high across the board and, therefore, it cannot explain outcomes. Certainly, withdrawals and rejections indicate that misjudgement occurs, but failed proposals are excluded from these analyses because there is no document on which estimating bargaining success. A failure is observed. This exclusion reduces further the explanatory power of the status quo as these are clear cut cases where disagreement is valued more than agreement. With all these caveats in mind, we will nevertheless include in the inferential analysis a proxy of the disagreement value.

\section{Institutions}

Let us consider other factors. We have argued that, in case of symmetry, both cooperative and non-cooperative bargaining solutions are driven by the disagreement value. But there is no symmetry within the conciliation committee. On the one hand, we have a fully represented collective actor, the Council, where each member can submit amendments. The agreed text is then subject to a perfunctory confirmation vote by the same actors involved in the committee negotiation. As Rasmussen (2008: 88) reminds us, the Council delegation is the Council. On the other hand, we have a delegation of a collective actor, the Parliament, where delegates can propose, individually, amendments during the negotiation and, collectively, a joint text to their whole chamber under closed rule. 
This set up makes the negotiations within each collective institution represented in conciliation asymmetric. Negotiation inside the Parliament, that is, between the parliamentary delegation and the whole assembly, is a case of majority-rule bargaining under closed rule. Negotiation inside the Council is a case of (super)majority-rule bargaining under open rule. These differences are best analysed employing Baron and Ferejohn's (1989) extension of the Rubinstein model. This extended model indicates that members of the parliamentary delegation should enjoy significantly more proposal power vis-à-vis their colleagues in whole assembly than members of the Council delegation vis-àvis their own colleagues. Council delegates are hampered by both open rule and supermajority. ${ }^{6}$ This difference between the two delegations is common knowledge and structural; and its consequence can be interpreted through the counterintuitive lenses of the Schelling (1960) conjecture. Since members of the Council delegation are significantly more constrained, they are likely to demand a more accommodating stance from the more powerful parliamentary delegation. Counter intuitively, the power that these delegates enjoy in conciliation vis-à-vis their colleagues in the plenary is a source of structural weakness in the conciliation negotiations. Outcomes of these negotiations should therefore be biased in favour of the Council. ${ }^{7}$

This advantage could vary from case to case as well. Where the Treaty prescribes unanimity in the Council, each member's proposal power within this institution is even more inhibited, further strengthening the Council vis-à-vis the parliamentary delegation (N. McCarty and Meirowitz 2007: 294; Tsebelis 2002). Now it is the least accommodating Council member that will make demands on the parliamentary delegation. Baron and Ferejohn's model also indicates that, in majority bargaining under closed rule, proposal power increases in the size of the assembly because more legislators can be played off one another. But, as we have argued, this increased power should further weaken the parliamentary delegation in the conciliation negotiations.

Lastly, considering Garrett and Tsebelis' (1996) argument, we also control for the Amsterdam Treaty reform in the inferential analysis.

\section{Uncertainty, veto threats and reputation}

Unanimity in the Council and a larger assembly are two additional structural features that could work against the Parliament. But what are the instruments at its disposal to redress this structural weakness? What can the Parliament do to strengthen its position in the conciliation negotiations? ${ }^{8}$

\footnotetext{
${ }^{6}$ Permanent representatives, the de facto negotiators, are even more constrained because they cannot promise and deliver compromises without the consent of their ministers (Tsebelis and Money 1997: 204).

7 Tsebelis and Money (1997: 176-9) note also how its unit rule to take decisions as well as the limited restrictions imposed by the parent chambers (negotiations cover the entire bill, and it is possible to find innovative solutions and to trade across issues) offer the committee the capacity to reach many different compromises. This can clearly be detrimental to the assembly. However, greater emphasis has been put on germaneness over the years. The two delegations bargain over a four column working document listing the second reading of the Parliament and the common position of the Council as well as the Council's opinion on the Parliament position and the updated comments of the parliamentary delegation.

${ }^{8}$ We will not consider two factors: representativeness of the parliamentary delegation and cohesiveness of the chambers. Representativeness matters, as Tsebelis and Money (1997: 110-8) remind us, but Rasmussen (2008) finds that the delegation tends to reflect the composition of the whole assembly by political groups, as prescribed by the rules of procedures. There are exceptions though; the largest parties tend to be overrepresented and, in six out of the 86 procedures analysed, the delegates' positions differed from those of their party colleagues in the assembly. For codecision cases in general, Costello and Thomson (2011) find that a representative rapporteur is beneficial to the Parliament (whether her report was amended by the plenary,
} 
Given its structural disadvantage, we may wonder what motivates the Parliament to move to conciliation. One factor could work in its favour: incomplete information. Consider a proposer facing, with a given probability, two types of receivers (moderate and extremist) with low and high disagreement values respectively. Her take-it-or-leave-it offer is more accommodating if the probability of dealing with an extreme receiver is high and her utility difference between an aggressive and an accommodating offer is small (McCarty and Meirowitz 2007: 295). This simple set up indicates that actors benefit from manipulating beliefs about an actor's type (i.e. reputation). A moderate receiver is better off if the proposer beliefs that she is an extreme type. These incentives are best analysed through signalling models. Although none has been developed with the conciliation committee in mind, several are on offer. In an influential model on veto threats, Matthews (1989) shows that the most informative equilibrium consists of an accommodating receiver signalling his true type and other receivers issuing a veto threat to whom the proposer offers concessions. Importantly, there is no guarantee for this equilibrium to exist. In a dynamic model of reputation building and bargaining over multiple bills, McCarty (1997) shows how a receiver has an incentive to reject a first-period proposal to build a reputation as an extreme type in order to obtain a better outcome from a second-period proposal. Given these incentives, the proposer may be more accommodating in the first period to avoid rejection on reputational grounds. This dynamics holds if receiver and proposer are sufficiently divergent.

In conciliation, there is no predetermined receiver or proposer and uncertainty may work either way. However, since the Council is fully represented, uncertainty about the type of Council the parliamentary delegation is dealing with is plausibly lower than the uncertainty

another factor based on an agency-drift type of argument, does not lend support however). The delegation could be more accommodating towards the Council than the whole assembly; or, it could be more recalcitrant. However, while an accommodating delegation may be detrimental to the assembly by agreeing on a joint document that is farther from the assembly position; it is unclear why a recalcitrant delegation should produce the same outcome. Actually, a chamber may have an incentive to create a recalcitrant committee as it could be a more effective intercameral negotiator (Gailmard and Hammond 2011). Unfortunately, it is very hard to determine the nature of the delegation because it ultimately depends on (a speculation on) the location of the status quo. Assume that we know the location of the median voter in the delegation and in the assembly. To determine whether the delegation is accommodating or recalcitrant we need to know the position of the (unanimity or qmv)-pivot in the Council. But to determine this, we ultimately need to know, or speculate on, the position of the status quo.

Related to representation are König et al.'s (2007) findings that higher parliamentary cohesiveness diminishes Council's and increases Parliament's success rates, and that lower Council cohesiveness increases parliamentary success. König et al. argue that 'the winset of less cohesive non-unitary institutional actors is larger. Because more cohesive non-unitary institutional actors accept fewer alternatives that beat the status quo, the bargaining outcome is expected to shift towards them' (289-90). However, the relation between cohesiveness and the size of the winset of the status quo is highly conjectural and changes direction with different decision rules. Consider cohesion as the inverse of the radius $r$ of a Y-centred yolk of a majorityvoting collective player. The Y-centred wincircle, with radius $d+2 r$ (where $d$ is the distance between $\mathrm{Y}$ and the status quo), defines an upper bound - there are no points of the winset of the status quo located outside it. By definition a decrease in cohesiveness increases the wincircle, but it is not always the case that an increased wincircle will entail an increase in the size of the winset of the status quo' (Tsebelis 2002: 48). Tsebelis provides an example of an increase in winset as the wincircle shrinks (i.e. as cohesiveness increases). Albeit anecdotal, the rejection by the Parliament of the joint text on biotechnological inventions seems to originate from a diminished cohesiveness (and smaller winset) after the European elections (Rittberger 2000: 563). For collective actors deciding by qualified majority, the so-called $q$-circle determines the radius and centre of the wincircle. Lower cohesion (i.e. larger yolk) is actually more likely to reduce the size of the wincircle and winset, although one can find counterexamples (Tsebelis 2002: 53). 
about the type of full assembly the Council delegation is facing. ${ }^{9}$ Potential benefits for the Parliament may lie here. The conciliation process can be plausibly described as a situation whereby the Council (proposer) makes a take-it-or-leave-it offer to the full Parliament (receiver), conditional to the support from a parliamentary delegation under open rule.

Since dossiers get to the conciliation stage because the positions of the Council and the Parliament differ significantly, even the most accommodating parliamentary delegation would have the incentive to issue a veto threat, at the risk of producing an uninformative babbling equilibrium (Matthews 1989). Nevertheless, under which conditions is a threat of parliamentary veto likely lead to concessions from the Council? Unfortunately, formal models do not offer much. ${ }^{10}$ We pay particular attention to the leading players involved in the conciliation negotiations - the president of the Council and the rapporteur of the Parliament - because they are widely recognized as being influential relay actors (e.g. Farrell and Héritier 2004; Rasmussen 2005). Rapporteurs from large parties or in a position of leadership in the Parliament are more likely to make good on veto threats because they have more resources to sanction defection in the assembly. Consequently, they should be able to extract more concessions from the Council. The ability to issue credible threats by rapporteurs from parties represented in the Council may be instead undermined primarily because their allegiance is also with the national parties in government. If the president of the Council comes from new member states, it is plausible to suggest that she would be more easily subject to belief manipulation as she is still learning the ropes of negotiation. She may also be facing higher reputational costs of a failed negotiation (Hosli, Mattila, and Uriot 2011). This could work in favour of the parliamentary assembly. Finally, McCarty's (1997) model suggests the Council to be more accommodating at the beginning of the parliamentary term, there may be non-trivial reputational incentives operating within the assembly at large.

There is no agreement on the impact of these factors in the literature. Costello and Thomson (2011: 341) also expect large party rapporteurs to be more successful because they 'can credibly claim to be more in touch with the views of the majority of MEPs' (see also Farrell and Héritier 2004). König et al. (2007) argue for the opposite. A smaller party rapporteur would extract more concessions as she would hold more extreme views. ${ }^{11}$ Both works fail to find party allegiance to have an impact. Costello and Thomson (2011) also find that the Parliament has less success in codecision when the rapporteur is in a position of leadership. They argue that 'rapporteurs who are political leaders will find it difficult to convince their counterparts [i.e. the Council] that they are unable to compromise' (342). However, why shouldn't this rapporteur take advantage of her greater control of the assembly to extract more concessions from the Council instead?

\section{Implementation}

We conclude considering how expectations about the implementation of a measure may affect the resolve of the Council and Parliament. This factor is ignored by the literature on

\footnotetext{
${ }^{9}$ Benedetto (2005) argues that bargaining inside the Parliament is more transparent than bargaining inside the Council and this should work in favour of the latter institution. This is the case prior to getting to conciliation. During these negotiations however, the whole Council is in full view, whereas the whole assembly is not.

${ }^{10}$ Ingberman and Yao (1991) analyse the consequences of a receiver successfully issuing a commitment threat of the sort: "I'll veto any bill that is not in the set C" (362), but this model is silent on the circumstances in which the receiver has the incentive and ability to make such a threat (Cameron 2000: 197).

${ }^{11}$ Both are predominantly preference-based arguments. König et al. (2007: 291) state that 'sending agents with extreme positions is advantageous for the (median) institutional actor' (but, operationally, they consider rapporteurs from the liberal party as extremists). On the issue of representativeness see note 8 .
} 
legislative bargaining, but re-election minded politicians are ultimately concerned about the outcomes of their decisions: how the implementation of a measure delivers benefits to their constituency. We will consider two issues.

First, another significant finding of König et al. (2007) is the importance of the opinion of the Commission in determining the relative success of the Parliament and Council in conciliation. The Commission may be able to exercise influence under favourable circumstances, when it enjoys some informational advantages or manages to assemble support from non-legislative actors (König et al. 2007; Moravcsik 1999; Pollack 2003; Rasmussen 2003). But perhaps, aside from informal influence, the views of the Commission matter simply because its formal role in implementation matters. The Commission is directly in charge of implementation when legislative provisions confer upon it the power to take policy decisions. Even when no provisions foresee its involvement, this supranational bureaucracy is entrusted with the power to initiate proceedings against possible infringements by national administrations (e.g. Börzel 2001; Pollack 2003).

This leads us to our second issue. The relative involvement in policy execution of the Commission and national administrations vary across measures, and the ex-ante and expost mechanisms $^{12}$ for overseeing implementation that are available to ministers and parliamentarians vary systematically as well (Franchino 2007: 240-4). Where the Commission is the main implementer, each minister must rely on the collective will of the Council to exercise control over the supranational executive, for instance via the comitology procedures. For national execution, ministers, as head of their departments, are instead individually in charge of overseeing implementation and they have at their disposal a wider array of ex-post control mechanisms. Parliamentarians are in the opposite position. They have at their disposal a greater array of ex-post mechanisms when a measure is mostly implemented by the single Commission rather than the several national authorities. Unsurprisingly, compared to ministers, parliamentarians prefer greater involvement of the latter at the expense of the former (Franchino 2007: 285-6). Because oversight via legislative design is more important to parliamentarians than ministers when national authorities are the primary implementers, we should expect them being less accommodating at the legislative stage. Because ex-post oversight is collective rather than individual when the Commission is the primary implementer, we should expect ministers being less accommodating at the legislative stage.

\section{Text-based measures of legislative bargaining success}

There are essentially two methods to measure success in legislative bargaining. The first one is based on interviewing key participants in the decision-making process. With the help of expert interviews, scholars identify the key cleavages underlying the adoption of a bill and estimate, for instance, the positions of the actors involved, the saliency they attach to each controversy as well as the location of the status quo. This approach has been the basis for important contributions in the study of EU legislative politics (e.g. Costello and Thomson 2011; König et al. 2007; Thomson et al. 2006; Thomson 2011). There is a limit however on how far back in time you can go and still produce valid estimates, both because memory fades and the availability of experts diminishes. For instance, Thomson et al. (2006) quite reasonably select only proposals pending in either 1999 or 2000. Additionally,

\footnotetext{
${ }^{12}$ Legislative design is an ex-ante control mechanism over implementation, while interpellations and inquiries are examples of ex-post control mechanisms (e.g. Epstein and O’Halloran 1999; Huber and Shipan 2002).
} 
because it is hard to replicate the measurement process, reliability may be a problem. Multiple experts and documentary evidence are however used to validate the data.

The second approach is based on comparing documents and producing measures of similarity. For instance, Tsebelis et al.'s (2001) study on the success of parliamentary amendments compares documents of the Commission and the Council with documents of the Parliament and produces an ordinal measure of the extent to which parliamentary amendments are adopted by the other institutions. This technique allows scholars to go quite far back in time, while the measurement process can be more easily replicated. However, even though several coders are employed, reliability may still be an issue.

Since we want to analyse the full history of conciliation negotiations, we will employ the second approach. To minimize reliability problems and facilitate replication, we use Slapin and Proksch's (2008; 2009) computer-based Wordfish scaling algorithm. Wordfish estimates positions based on word frequencies in text documents on a single dimension. Frequencies are assumed to be generated by a Poisson process, hence the stochastic component of the model is

$Y_{i j} \sim \operatorname{Poisson}\left(y_{i j} \mid \lambda_{i j}\right)$

whereas the systematic component is

$\lambda_{i j}=\exp \left(\alpha_{i}+\psi_{j}+\beta_{j} \omega_{i}\right)$.

where $y_{i j}$ is the count of word $j$ in document $i, \alpha$ and $\psi$ are document and word fixed effects respectively, $\beta$ is an estimate of a word specific weight capturing the importance of word $j$ in discriminating between positions, and $\omega$ is the estimate of document $i$ 's position. The systematic component is estimated through an expectation maximization algorithm. This procedure has several qualities, which are well explained by Slapin and Proksch (2008); it has also some problematic features though. It constrains positions on a single dimension, estimated by the parameter $\omega$. The fact that there tends to be a privileged dimension of conflict in bicameral bargaining brings some solace (Tsebelis and Money 1997: 90), but more than one dimension may persist in these negotiations (König et al. 2007).

Our estimates are based on three official documents: the second reading of the Parliament, the Council common position and the joint text. In Appendix A, we explain in detail how the original documents have been treated to produce the data on which the Wordfish procedure is run. In Appendix B, we examine the validity of these estimates comparing them with those produced using five documents (adding, therefore, the Commission proposal and the first reading of the Parliament), hand-coding and expert interviews.

\section{Dataset and variables}

As illustrated in Table 1, 184 codecision dossiers have reached the conciliation stage since the entry into force of the Maastricht Treaty to February 2012. On three occasions, the committee failed to produce a joint text. Because we cannot produce a measure of bargaining success, these dossiers drop out from our dataset. The documents of the dossiers on trans-European transport networks (COD/1994/0098) and on the Socrates financial framework (COD/1997/0103) differ only with regard to maps or figures. They are not amenable to our textual analysis and they drop out as well. In sum, the final dataset comprises 179 dossiers, which include, from Commission proposal to joint text, 537 
documents. ${ }^{13}$ The policy areas most frequently covered are environment, internal market and transport.

We take the perspective of the Parliament and we measure its bargaining success in a given dossier $d$ as follows

$$
\text { EP success }_{d}=\left\{\begin{array}{l}
1 \text { if }\left|\omega_{E P 2}-\omega_{J T}\right|<\left|\omega_{C P}-\omega_{J T}\right| \\
0 \text { if }\left|\omega_{E P 2}-\omega_{J T}\right|>\left|\omega_{C P}-\omega_{J T}\right|
\end{array}\right.
$$

EP success takes the value of 1 if the absolute difference between the $\omega$ estimates for the second parliamentary reading and the joint text is smaller than the difference between the estimates for the Council common position and the joint text.

We consider the following explanatory factors. As far as institutional features are concerned, parliamentary bargaining success should be negatively affected in dossiers where the Treaty prescribes unanimity for Council's decisions. We include a variable Unanimity which takes the value of one in these circumstances. To account for the Amsterdam Treaty reform, which may have strengthened the Parliament, we include Codecision II that takes the value of one if committee negotiations have taken place after 1 May 1999. Lastly, to account for Baron and Ferejohn's (1989) result that a larger membership should work against the Parliament, we include the variable MEPs, measuring the size of the assembly at the time of the adoption of the joint text by the committee.

Moving on to uncertainty and veto threats, we have argued that rapporteurs from large parties or in a position of leadership within the Parliament may service better their assembly. Large party rapporteur takes the value of one if the rapporteur is from either the European People's Party or the Party of European Socialists, while, as in Costello and Thomson (2011: 348), Leader rapporteur takes the value of one if the rapporteur held a leadership position. Rapporteurs from national parties that are represented in the Council may instead be less effective in extracting concessions. Government rapporteur takes the value of one if the rapporteur belongs to a national party that is in government at the time of adoption of the joint text. Beliefs about parliamentary types may be more easily manipulated when a Council president comes from a new member state. President state seniority is the natural logarithm of the number of completed years the country of the president has been an EU member at the time of adoption of the joint text. It should be negatively associated with parliamentary success.

The reputational incentives discussed by McCarty (1997) are measured by the number of completed months between the beginning of the parliamentary term and the adoption of the joint text (Term length). The variable should be negatively associated with success if these incentives are more powerful at the beginning of term.

As far as implementation is concerned, the influence of the Commission in codecision is measured by the share of parliamentary amendments that are rejected by this institution (Commission rejection). Lastly, because national administrations are relatively more involved in implementation than the Commission in case of directives, we use the indicator Directive, taking the value of one for this type of instrument, to measure the relative involvement of the two sets of implementers. If oversight via legislative design is more

\footnotetext{
${ }^{13}$ PreLex and EurLex were the primary sources but, for dossiers prior to the V legislative term, we had to collect documents from either the Official Journal or the public registers of the Parliament and the Council.
} 
important to parliamentarians than ministers in these circumstances, we should expect this variable to be positively associated with parliamentary success.

We conclude with two last factors. Notwithstanding our earlier discussion on the disagreement value, we include a variable, New act, which takes the value of one if the measure is not amending prior legislation. A negotiating failure in these circumstances would leave the Parliament empty-handed as there would be no EU law regulating the issue at hand. National governments would lose the benefits of EU-wide harmonization but their national regulatory capacity would be unaltered. We should expect the Council to benefit if indeed the disagreement value of ministers is higher than that of parliamentarians. Lastly, some measures are part of the same legislative package and are likely to share common features. We decided to control for this aspect with a variable, Package, that takes the value of one if dossiers either specifically mentions that are part of a package or have the same date of adoption of the joint text and same responsible parliamentary committee. Deals within the Council across measures of the same package could make this institution less amenable to compromise. Table 2 provides a summary of these variables with some descriptive statistics.

\section{< TABLE 2 APPROX HERE >}

\section{Parliamentary success in conciliation committee negotiations}

Overall, conciliation negotiations are biased against the Parliament. The estimate of the joint text is closer to the position of the Parliament in only 54 of the 179 dossiers. In each legislative term, the joint text has been on average more similar to the common position than to the second parliamentary reading. The best performance for the Parliament was during the fifth term where 33 out of the 86 dossiers reaching conciliation produced joint texts that were more similar to its reading. In Table 3, we show the results of binomial tests with an epiphenomenal conciliation committee as null hypothesis (i.e. where the probability of parliamentary success is 0.5 , a split-the-difference outcome). The probability that the expected frequency of success $(k)$ in case of an epiphenomenal committee exceeds the observed frequency of success is above 99 percent in most cases. In other words, the Parliament significantly underperforms in these negotiations.

\section{< TABLE 3 APPROX HERE >}

In the earlier days, the joint text differed from the Parliament second reading and from the Council common position more than the extent to which these latter two documents differed from each other. ${ }^{14}$ The frequency of these cases has diminished over time however. They were the majority of observations in the third and fourth legislative term, but they have not exceeded thirty percent ever since. This could indicate that, over time, the two chambers are relying on conciliation as a more proper dispute settlement mechanism.

What determines parliamentary success? Table 4 lists the results of the estimation of binomial models with a probit link function. ${ }^{15}$ Institutions matter. The probability of parliamentary success decreases by between 24.9 and 26.7 percentage points when the Council decides by unanimity. This decision rule confers a veto power to the Council member that is the least accommodating towards the demands of the Parliament. This weakness clearly emerges from the data. Additionally, the probability of success has increased by between 14.9 and 18 percentage points after the reform of the codecision

\footnotetext{
${ }^{14}$ In other words, for any given dossier, $\left|\omega_{J T}-\omega_{E P 2}\right|>\left|\omega_{E P 2}-\omega_{C P}\right|$ and $\left|\omega_{J T}-\omega_{C P}\right|<\left|\omega_{E P 2}-\omega_{C P}\right|$.

${ }^{15} \mathrm{We}$ employ a probit link because EP success reflects an underlying interval variable. Hence, its cumulative distribution is normal.
} 
procedure introduced by the Treaty of Amsterdam. Despite evidence to the contrary (Hix 2002; Kasack 2004), it seems that these changes have actually strengthened the Parliament's hand. This is in line with Garrett and Tsebelis' (1996) analysis of parliamentary powers under the first version of codecision. The size of the parliamentary assembly appears instead irrelevant.

$<$ TABLE 4 APPROX HERE >

The results from the belief-manipulation expectations are weaker. We do not find evidence that rapporteurs in a position of leadership can extract more concessions from the Council. Costello and Thomson's (2011) opposite expectation is also disconfirmed. Moreover, the Parliament does not benefit if the rapporteur is from a party represented in the Council. If instead she comes from a large party, the probability of parliamentary success increases by between 13.1 and 14.9 percentage points. Costello and Thomson (2011) put more emphasis on representation to explain this outcome. We have argued that large party rapporteurs can rely on greater resources to make good on veto threats and, therefore, they can be more successful.

Moving on, there is weak evidence that Council presidents coming from newer member states are more accommodating toward the Parliament, perhaps because their beliefs are more easily manipulable. In 1998, Greece has been a member of the EU for seventeen years, while Austria just joined the three years earlier. If a Greek rather than an Austrian minister presided over the Council in the second semester of that year, the likelihood of parliamentary success would lower by 13.2 percentage points.

Reputational incentives clearly do not seem to operate within the assembly at the beginning of a term as McCarty's (1997) model suggests. Actually, there is weak evidence to the contrary. A Parliament facing elections in six months is 7.9 percentage points more likely to win in conciliation than a Parliament six months into its term. A weak learning process may be at place here.

Implementation instead matters. If the Commission decides to reject all of the second reading amendments of the Parliament, rather than only half of them, the chances that the Parliament would win in conciliation diminishes by 14.4 percentage points. This is in line with the finding of König et al. (2007), although we tend to prefer a causal explanation based on the formal role entrusted upon the Commission in implementation rather than on informal bargaining resources. Certainly, the two causal stories are not mutually exclusive and may be related.

Results also indicate that the probability of parliamentary success increases by 19.5 percentage points in case of directives. When national administrations are more involved in implementation than the Commission is, parliamentarians are less accommodating because legislative design is the primary control mechanism at their disposal. On the other hand, ministers are more accommodating because they can rely on a wide array of ex-post control mechanisms. In other words, parliamentarians value legislative design as control mechanism much more than ministers do.

Finally, the probability of parliamentary success diminishes by 12.5 percentage points when next acts are negotiated. In these circumstances, a more accommodating Parliament may indeed indicate that its members attach a lower disagreement to the measure at hand than the one assigned by ministers. In other words, a negotiating failure is more costly to parliamentarians. 


\section{Conclusion}

From the standpoint of the Parliament, this study offers solace and annoyance. Solace because the Amsterdam Treaty reform appears to have delivered the benefits the Parliament expected and because the phasing-out of unanimity from Council proceedings has strengthened the hand of the assembly in conciliation negotiations. Annoyance because the set-up of the conciliation committee remains structurally biased against the Parliament. Perhaps counterintuitively, it is the strength of the parliamentary delegation vis-à-vis the full assembly that is the source of the latter's weakness vis-à-vis the Council. Likewise, it is the weakness of each minister vis-à-vis her colleagues that is the source of strength for the whole Council.

Despite this structural weakness, getting to conciliation is not a foregone conclusion. The Parliament has managed to negotiate a joint text that is closer to its second reading in 30.2 percent of dossiers that have reached conciliation. This proportion increases to 37.6 percent in the current setting (i.e., post-Amsterdam Treaty procedure and majority voting in the Council). What else explain parliamentary success? We have some support for theories that put emphasis on uncertainty and reputation. A veto threat by a rapporteur belonging to a large party is more executable and may induce the Council to be more accommodating.

Evidence about the importance of implementation is more robust however. Of whom the Commission takes side matters because, we contend, its role in implementation is far from trivial. Politicians cannot ignore the effective delivery of a measure's benefits. Additionally, when national administrations are more involved in implementation than the Commission, because legislative design is much more valued as control mechanism by parliamentarians than ministers, the former are less accommodating than the latter.

The Parliament could also take advantage of other weapons, such as explicitly setting credible restrictions over the set of acceptable solutions (Tsebelis and Money 1997: 176). Indeed, the self-imposed rules of representativeness of its delegation, which Rasmussen (2008) finds to be operating well, could actually be counterproductive if interpreted through the lenses of intercameral bargaining (Gailmard and Hammond 2011). We have noted the difficulties in determining the nature of the parliamentary delegation, but an area of future research could be to understand if the Council's negotiating stance influences the selection of parliamentary delegates. 


\section{Table 1: The incidence of conciliation}

EP legislative term Codecision proposal

\begin{tabular}{lccc} 
IV (1994-9) & 270 & 67 & 24.8 \\
V (1999-2004) & 482 & 86 & 17.8 \\
VI (2004-9) & 541 & 24 & 4.4 \\
VII (2009-) & 270 & 7 & 2.6 \\
Total & 1563 & 184 & 11.8 \\
\hline
\end{tabular}

Source: OEIL database, accessed on 29 February 2012.

Note: Three conciliation negotiations failed to produce a joint text, one in the IV Parliament, one in each the VI and VII Parliament. The Parliament has rejected four joint texts. 
Table 2: Descriptive statistics

\begin{tabular}{|c|c|c|c|c|c|}
\hline Variable & Description & Mean & Standard dev. & Min & Max \\
\hline \multirow[b]{2}{*}{ EP success } & Dependent variable & & & & \\
\hline & $\begin{array}{c}=1 \text { if }\left|\omega_{E P 2}-\omega_{J T}\right|<\left|\omega_{C P}-\omega_{J T}\right| .0 \text { otherwise } \\
\text { Institutions }\end{array}$ & 0.3 & 0.46 & 0 & 1 \\
\hline Unanimity & $=1$ if Council unanimity is required. 0 otherwise & 0.08 & 0.27 & 0 & 1 \\
\hline Codecision II & $=1$ if Amsterdam Treaty procedure. 0 otherwise & 0.65 & 0.48 & 0 & 1 \\
\hline \multirow[t]{2}{*}{ MEPs } & Number of MEPs & 639.13 & 54.69 & 518 & 785 \\
\hline & Veto threats and reputation & & & & \\
\hline Leader rapporteur & $=1$ if rapporteur in leadership position. 0 otherwise & 0.26 & 0.44 & 0 & 1 \\
\hline Large party rapporteur & $=1$ if rapporteur from EPP or PSE. 0 otherwise & 0.66 & 0.47 & 0 & 1 \\
\hline Government rapporteur & $\begin{array}{l}=1 \text { if rapporteur from party in government. } 0 \\
\text { otherwise }\end{array}$ & 0.4 & 0.49 & 0 & 1 \\
\hline Presidency state seniority & $\ln$ (no. of membership years of president country) & 3.11 & 0.8 & 1.1 & 3.93 \\
\hline \multirow[t]{2}{*}{ Term length } & No. of months into parliamentary term & 80.84 & 41.69 & 8 & 147 \\
\hline & Implementation & & & & \\
\hline Commission rejection & Share of EP amendments rejected by Commission & 0.46 & 0.31 & 0 & 1 \\
\hline \multirow[t]{2}{*}{ Directive } & $=1$ if directive. 0 otherwise & 0.64 & 0.48 & 0 & 1 \\
\hline & Other factors & & & & \\
\hline New act & $=1$ if new act. 0 otherwise & 0.56 & 0.5 & 0 & 1 \\
\hline Package & $=1$ if part of package. 0 otherwise & 0.27 & 0.45 & 0 & 1 \\
\hline
\end{tabular}




\section{Table 3: Frequency of parliamentary success}

\begin{tabular}{lcccc} 
& & \multicolumn{3}{c}{ EP legislative term } \\
\cline { 3 - 5 } EP success & 54 & IV & V & VI \\
\cline { 3 - 5 } $\mathrm{N}$ & 179 & 59 & 33 & 6 \\
$\mathrm{Z}$-statistic & -5.31 & -4.30 & -2.16 & 23 \\
$\operatorname{Pr}(\mathrm{k}>=$ EP success $)$ & 1.000 & 1.000 & 0.989 & -2.29 \\
\hline
\end{tabular}

Note: One-sided binomial probability tests; $k$ is the expected frequency in case of $\mathrm{H} 0=.5$ 
Table 4: Determinants of parliamentary success

\begin{tabular}{|c|c|c|c|}
\hline \multirow{2}{*}{\multicolumn{4}{|c|}{ Institutions }} \\
\hline & & & \\
\hline Unanimity & $\begin{array}{c}-1.043^{*} \\
(0.541)\end{array}$ & $\begin{array}{c}-1.222^{* * *} \\
(0.560)\end{array}$ & $\begin{array}{c}-1.200^{* *} \\
(0.546)\end{array}$ \\
\hline Codecision II & $\begin{array}{l}0.471^{*} \\
(0.251)\end{array}$ & $\begin{array}{c}0.606^{* *} \\
(0.259)\end{array}$ & $\begin{array}{c}0.634 * * \\
(0.266)\end{array}$ \\
\hline MEPs & $\begin{array}{l}-0.153 \\
(0.217)\end{array}$ & $\begin{array}{l}-0.175 \\
(0.231)\end{array}$ & $\begin{array}{l}-0.195 \\
(0.234)\end{array}$ \\
\hline \multicolumn{4}{|c|}{ Veto threats and reputation } \\
\hline Leader rapporteur & & $\begin{array}{c}0.190 \\
(0.242)\end{array}$ & $\begin{array}{c}0.257 \\
(0.256)\end{array}$ \\
\hline Large party rapporteur & & $\begin{array}{c}0.497 * * \\
(0.225)\end{array}$ & $\begin{array}{c}0.476 * * \\
(0.236)\end{array}$ \\
\hline Government rapporteur & & $\begin{array}{l}0.0417 \\
(0.215)\end{array}$ & $\begin{array}{l}-0.0483 \\
(0.240)\end{array}$ \\
\hline President state seniority & & $\begin{array}{c}-0.198 \\
(0.140)\end{array}$ & $\begin{array}{c}-0.269^{*} \\
(0.151)\end{array}$ \\
\hline Term length & & $\begin{array}{c}0.456 \\
(0.281)\end{array}$ & $\begin{array}{l}0.582^{*} \\
(0.300)\end{array}$ \\
\hline \multicolumn{4}{|c|}{ Implementation } \\
\hline Commission rejection & & & $\begin{array}{c}-1.015^{* *} \\
(0.396)\end{array}$ \\
\hline Directive & & & $\begin{array}{c}0.706^{* * * *} \\
(0.251)\end{array}$ \\
\hline \multicolumn{4}{|c|}{ Other factors } \\
\hline New act & $\begin{array}{l}-0.364^{*} \\
(0.208)\end{array}$ & $\begin{array}{c}-0.362^{*} \\
(0.216)\end{array}$ & $\begin{array}{c}-0.433^{*} \\
(0.246)\end{array}$ \\
\hline Package & $\begin{array}{l}-0.237 \\
(0.244)\end{array}$ & $\begin{array}{c}-0.318 \\
(0.262)\end{array}$ & $\begin{array}{l}-0.328 \\
(0.282)\end{array}$ \\
\hline Constant & $\begin{array}{c}0.460 \\
(1.334)\end{array}$ & $\begin{array}{c}0.362 \\
(1.547)\end{array}$ & $\begin{array}{c}0.596 \\
(1.646)\end{array}$ \\
\hline $\mathrm{N}$ & 179 & 179 & 179 \\
\hline Log-pseudolikelihood & -102.8 & -98.49 & -90.74 \\
\hline Wald chi2 & 11.79 & 21.16 & 38.01 \\
\hline
\end{tabular}

Robust standard errors in parentheses

$* * * \mathrm{p}<0.01, * * \mathrm{p}<0.05, * \mathrm{p}<0.1$

Dependent variable: EP success. 


\section{Appendix A From official documents to Wordfish-usable data}

The official documents of the two institutions and of the conciliation committee need to be standardized and processed in order to become usable data for Wordfish. We deleted unnecessary parts, for example references to the author (Council, Parliament or conciliation committee), the competent directorate-general or subunit of the Commission and the number of pages. Abbreviations referring to units of measurement, mathematical or chemical formula, irrelevant footnotes, such as those referring to international conventions or EU legislation, and acronyms of international organizations or institutions were removed with the use of Notepad++, a text editing program. The same program was used to delete non-English words referring to national institutions. ${ }^{16}$

We then extensively reviewed the documents and corrected the mistyped and misspelt words ${ }^{17}$ employing also the spelling and grammar check of Microsoft Word. Extensive review was necessary because Microsoft Word tool detects mistyped, rather than misspelt, words. For example, a word 'form' that should be 'from' is not detected because it is correctly written, even though it has a different meaning. Moreover, the tool is unable to detect words which contain numbers (e.g. 'collect' instead 'collect').

The documents were then converted into txt files and run through JFreq, a program that removes numbers and stopwords (e.g. 'and', 'then', 'but') as well as other recurrent words in legislative texts ('article', 'annex', 'paragraph', 'whereas', 'OJ') ${ }^{18}$ and stems the remaining ones according to the English dictionary. JFreq creates a term-document matrix in comma-separated value format that can be uploaded by Wordfish.

\section{Appendix B Validation}

We have compared our estimates with those derived from three alternative procedures: Wordfish estimation employing five official documents, hand-coding and expert surveys. In this appendix, we report the results of this validation exercise.

\section{Comparison with EP success estimates based on five documents}

According to Slapin and Proksch (2008), the stability of the word parameters improves if the estimation is performed using more and longer documents. We do not have a problem of length in our case, but we should consider the possibility in including five documents in the estimation procedure, namely adding the Commission proposal and the first reading of the Parliament. ${ }^{19}$ Note that this is not how the conciliation committee operates. The first two documents are ignored. Despite some freedom of manoeuvre (Tsebelis and Money 1997: 176-9), negotiations tend to be germane, with the two delegations bargaining over a four-column working document listing the second reading of the Parliament and the common position of the Council, along with the updated positions of the two delegations.

\footnotetext{
${ }^{16}$ This is because we employed JFreq stemming process which relies on the English dictionary. We kept however Latin and foreign words that are commonly used in the English lexicon, such as inter alia, mutatis mutandis and leitmotiv.

${ }^{17}$ Because we had to scan older documents, which were unavailable in electronic format, and employ an optical character recognition software, several words were indeed mistyped or misspelt.

${ }^{18}$ Stopwords and recurrent words are uninformative because they do not discriminate across documents. Moreover, they make the estimation procedure more inefficient. The file listing stopwords and recurrent words is uploaded it into JFreq.

${ }^{19}$ Using documents from different dossiers is meaningless because it implies imposing a single dimension upon different policy areas.
} 
We have produced the $\omega$ estimates of the second reading of the Parliament, the common position of the Council and the joint text using five documents, and computed the variable $E P$ success as explained in the main text. This variable is positively and significantly correlated with the EP success measure based on three documents, but the correlation is not substantively large (Spearman's correlation coefficient rho is $0.3380, \mathrm{p}<0.001$ ).

Conciliation negotiations are biased against the Parliament according to this measure as well. The estimate of the joint text is closer to the position of the Parliament in only 74 of the 179 dossiers. In Table 1A, we show the results of binomial tests with an epiphenomenal conciliation committee as null hypothesis. The probability that the expected frequency of success, in case of an epiphenomenal committee, exceeds the observed frequency is above 99 percent in the full sample and the fourth legislative term. There are some important differences as well tough. The probability of parliamentary success is not significantly less than 0.5 in the fifth and sixth terms. The five-text estimation procedure picks up then a strengthening of the Parliament over time (not because of Codecision II though, as its effect is insignificant) or, perhaps, finds it harder to distinguish between the last three documents as legislators become more selective in relying on conciliation.

$<$ TABLE 1A APPROX HERE >

What else can explain these differences? And, more importantly, which measure is more valid? If changes have occurred during a procedure, the first two documents may be so different from the last three that it would be meaningless to impose a single dimension upon all five texts. Several variables we examined ${ }^{20}$ do not explain this difference. Two seems relevant however. First, as the share of parliamentary amendments rejected by the Commission decreases, the two measures diverge. This could indicate greater parliamentary intervention and, thus, difference across the five legal texts. Imposing a single dimension could therefore be problematic. Second, the two measures diverge when the Council decides by unanimity. The five-document estimate displays a split-the-difference outcome (six parliamentary wins out for fourteen cases), while the three-document estimate displays a poor parliamentary performance (only one parliamentary win). Certainly, selecting a measure on the basis of whether it corroborates our expectation is questionable, but a measure indicating equal power between Parliament and Council when the latter decides by unanimity raise doubts. Below we discuss how hand-coding estimates also correlate more with Wordfish estimates based on three rather than five documents. On balance, the former procedure seems to produce more valid measures.

\section{Comparison with hand-coded estimates}

Because Wordfish has never been used to extract policy positions from legislative documents, we have compared its estimates with those derived from hand-coding. We randomly selected twenty legislative dossiers ${ }^{21}$ and compared the joint text with the second parliamentary reading and the Council common position.

We coded more than five hundred modifications, roughly following Tsebelis et al.'s (2001). First, we determined whether the wording of the joint text provisions could be easily associated with the wording of the relevant provisions in either the reading of the

\footnotetext{
${ }^{20}$ Such as a change in procedure, rapporteur, Commission or commissioner responsible as well as the number of months passed between the parliamentary first reading and the Council common position.

21 These are: COD/2005/0191; COD/2004/0175; COD/2003/0168; COD/2001/0257; COD/1998/0336; COD/1998/0289; COD/1998/0195; COD/1997/0370; COD/1997/0176; COD/1997/0067; COD/1996/0085; COD/1997/0146; COD/1995/0209; COD/1995/0080; COD/1994/0222; COD/1994/0135; COD/1993/0471; $\mathrm{COD} / 1992 / 0426$
} 
Parliament or the Council common position. If the joint text adopted verbatim either version of the text, this amendment was labelled EP2 adopted or CP adopted. If the joint text modified either the Parliament's or Council's version without altering its substantive meaning, we labelled this amendment EP2 partially adopted or CP partially adopted.

Where we could not determine easily whether the provision in the joint text was more similar to either one of the other two documents' versions, we used three coding categories:

a) Partially changed for circumstances where the joint text provision modified by less than 40 percent of the wording of both the parliamentary and Council variant, b) Largely changed if the joint text provision modified by more than 40 percent such wording, and c) New/deleted when a new provision was introduced or both the Council's and the Parliament's variants were deleted. This classification scheme is illustrated in Table 2A.

$<$ TABLE 2A APPROX HERE >

This classification scheme errs on the side of caution. Given the complexity of some legal texts, determining whether the changed provisions are more similar to the Council's or the Parliament's variant is not an easy task. Take the following example. Article 6(1) of the draft decision on AIDS prevention (COD/1994/0222) was subject to several modifications throughout legislative procedure. The text of the Council common position was:

Article 6(1) In the course of implementing this programme, cooperation with non-member countries and with international organizations competent in the field of public health, in particular the United Nations, the World Health Organization and the Council of Europe.

The Parliament in the second reading deleted the italicized text above and added the bold text below:

Article 6(1) In the course of implementing this programme, cooperation with non-member countries and with international organizations in particular the United Nations, the World Health Organization, the Council of Europe, and non-governmental organizations competent in the field of public health or particularly involved in the fight against AIDS and the prevention thereof.

Finally, the joint text deleted the italicized text of the parliamentary reading, restated the Council text (underlined below) and added the bold text:

Article 6(1) In the course of implementing this programme, cooperation with non-member countries and with international organizations competent in the field of public health, especially the United Nations and in particular the World Health Organization, the Council of Europe and nongovernmental organizations, competent in the field of public health or particularly involved in the fight against AIDS and other communicable diseases and the prevention thereof.

In this situation, we could not determine whether the conciliation committee took a position closer to either of the other two institutions. We therefore coded this subunit as 'Partially changed'. We have been therefore rather conservative in deciding whether a text was closer to the position of one chamber in order to ensure an acceptable degree of intercoder reliability. We also replicated the coding several times in order to reduce subjective judgment and to make the procedure the most transparent and replicable as possible.

For each dossier, we then produced three values: $h_{E P 2}$ is the sum of the number of modifications that have been coded EP2 adopted or EP2 partially adopted, $h_{C P}$ is the sum of the modifications coded CP adopted or CP partially adopted, $h_{U}$ is the sum of the remaining modifications. For each dossier $d$, bargaining success has been determined as follows:

$$
\text { Bargaining success }_{d}=\left\{\begin{array}{c}
\text { CoM if } \max \left(h_{C P}, h_{E P 2}, h_{U}\right)=h_{C P} \\
E P \text { if } \max \left(h_{C P}, h_{E P 2}, h_{U}\right)=h_{E P 2} \\
\text { undetermined if } \max \left(h_{C P}, h_{E P 2}, h_{U}\right)=h_{U}
\end{array}\right.
$$


Success is assigned to the institution that has managed to insert in the final document a relative majority of amendments that are identical or highly similar to its version of the text. Success cannot be determined if a relative majority of changes cannot be easily associated with the version of either the parliamentary reading or the common position. Table $3 \mathrm{~A}$ illustrates the results of this exercise. Wordfish estimates coincide with the hand-coding estimates in nine out of the eleven dossiers where we can easily determine the winning institution through the hand-coding procedure. Wordfish estimates based on five documents perform instead more poorly. Only six dossiers display the same outcome as the one produced through hand-coding.

$<$ TABLE 3A APPROX HERE >

Hand-coding and Wordfish based on three documents produce therefore similar estimates. Certainly, there is a group of dossiers where hand-coding is difficult but, in these circumstances, it is better to rely on the more reliable and easily replicable Wordfish procedure.

\section{Comparison with expert-interviews estimates}

Finally, we compare our estimates with those derived from expert surveys conducted by König et al. (2007). This study is based on 54 dossiers that reached conciliation between 1999 and 2002. These dossiers comprise 74 issues on which there was disagreement between the two chambers. If we consider issues only, König et al. (2007) finds that the Parliament has succeeded in 56 percent of times, while the Council only in 26 percent. If we consider only dossiers having one conflicting issue, the Parliament succeeds 60 percent of times. Our Wordfish estimates for these 54 dossiers indicate instead that the Parliament is successful in only 39 percent of the cases. König et al. (2007) have cross-validated their

estimates with the data available from the DEU project (Thomson et al. 2006), but the two datasets overlap only on seven issues. Clearly, these differences are glaring and should be subject to further research. 
Table 1A: Frequency of parliamentary success ( $\omega$ estimates based on five documents)

\begin{tabular}{lcccc} 
& & \multicolumn{3}{c}{ EP legislative term } \\
\cline { 3 - 5 } EP success & IV & $\mathrm{V}$ & $\mathrm{VI}$ \\
$\mathrm{N}$ & 174 & 18 & 41 & 10 \\
$\mathrm{Z}$-statistic & 59 & 86 & 23 \\
$\operatorname{Pr}(\mathrm{k}>=$ EP success $)$ & -2.32 & -2.99 & -0.43 & -0.63 \\
\hline
\end{tabular}

Note: One-sided binomial probability tests; $k$ is the expected frequency in case of $\mathrm{H} 0=.5$

Table 2A: Classification scheme for hand-coding modifications

Can the joint text provision be easily associated with the relevant provision in either the reading of the Parliament or the Council common position?

\begin{tabular}{lc}
\multicolumn{2}{c}{ Yes } \\
\hline \multicolumn{1}{c}{ Substantive meaning } & Labels \\
\hline EP2 Amendment is adopted verbatim & EP2 adopted \\
CP Amendment is adopted verbatim & CP adopted \\
EP2 Amendment is partially adopted & EP2 partially adopted \\
CP Amendment is partially adopted & CP partially adopted \\
\hline & \\
\hline & No \\
Less than 40\% of the words of both texts modified & Partially changed \\
Ner than $40 \%$ of the words of both texts modified & Largely changed \\
\hline
\end{tabular}


Table 3A: Validity analysis of hand- and Wordfish-coding of bargaining success for twenty randomly selected dossiers

\begin{tabular}{|c|c|c|c|c|c|c|c|c|c|}
\hline & \multicolumn{7}{|c|}{ Number of modifications } & \multicolumn{2}{|c|}{ Bargaining success } \\
\hline & $\begin{array}{c}\text { EP } \\
\text { adopted }\end{array}$ & $\begin{array}{c}\text { EP partially } \\
\text { adopted }\end{array}$ & $\begin{array}{c}\mathrm{CP} \\
\text { adopted }\end{array}$ & $\begin{array}{c}\text { CP partially } \\
\text { adopted }\end{array}$ & $\begin{array}{l}\text { Partially } \\
\text { changed }\end{array}$ & $\begin{array}{l}\text { Largely } \\
\text { changed }\end{array}$ & $\begin{array}{c}\text { New/ } \\
\text { deleted }\end{array}$ & Hand-coding & Wordfish $^{1}$ \\
\hline COD/2005/0239 & 4 & 15 & 28 & 1 & 6 & 5 & 11 & CoM & $\operatorname{CoM}^{2}$ \\
\hline COD/2005/0191 & 5 & 6 & 67 & 3 & 11 & 7 & 7 & CoM & CoM \\
\hline COD/2004/0175 & 11 & 3 & 2 & 1 & 11 & 9 & 3 & undetermined & $E P^{2}$ \\
\hline COD/2003/0168 & 0 & 1 & 15 & 1 & 4 & 6 & 2 & CoM & CoM \\
\hline COD/2001/0257 & 8 & 4 & 2 & 0 & 9 & 1 & 1 & $E P$ & $E P^{2}$ \\
\hline COD/1998/0336 & 0 & 0 & 10 & 1 & 5 & 6 & 4 & undetermined & $E P$ \\
\hline COD/1998/0289 & 2 & 1 & 10 & 1 & 1 & 4 & 4 & CoM & $\operatorname{CoM}^{2}$ \\
\hline COD/1998/0195 & 2 & 1 & 7 & 2 & 4 & 5 & 3 & undetermined & $\operatorname{CoM}^{2}$ \\
\hline COD/1997/0370 & 0 & 2 & 3 & 0 & 1 & 4 & 2 & undetermined & $\operatorname{CoM}^{2}$ \\
\hline COD/1997/0176 & 5 & 2 & 1 & 0 & 2 & 0 & 0 & $E P$ & $E P^{2}$ \\
\hline COD/1997/0067 & 0 & 6 & 11 & 1 & 5 & 0 & 2 & CoM & CoM \\
\hline COD/1996/0085 & 4 & 14 & 25 & 1 & 23 & 14 & 16 & undetermined & $E P$ \\
\hline COD/1997/0146 & 3 & 2 & 4 & 0 & 6 & 0 & 2 & undetermined & CoM \\
\hline COD/1995/0209 & 0 & 0 & 5 & 0 & 2 & 0 & 0 & CoM & $E P$ \\
\hline COD/1995/0080 & 2 & 0 & 2 & 1 & 4 & 0 & 0 & undetermined & $E P$ \\
\hline COD/1994/0222 & 4 & 3 & 7 & 0 & 7 & 1 & 3 & undetermined & CoM \\
\hline COD/1994/0135 & 1 & 8 & 11 & 0 & 3 & 1 & 0 & CoM & CoM \\
\hline COD/1993/0471 & 0 & 0 & 6 & 1 & 1 & 0 & 0 & CoM & CoM \\
\hline COD/1992/0426 & 4 & 0 & 0 & 0 & 2 & 2 & 0 & undetermined & CoM \\
\hline COD/1992/0415 & 2 & 2 & 2 & 1 & 0 & 0 & 0 & $E P$ & $\operatorname{CoM}^{2}$ \\
\hline
\end{tabular}

${ }^{1}$ EP if EP success $=1$, CoM otherwise. ${ }^{2}$ Wordfish estimate employing five documents differs from the three-document estimate. 


\section{Bibliography}

Achen, Christopher H. 2006. "Institutional Realism and Bargaining Models." In The European Union Decides, ed. Robert Thomson, Frans N. Stokman, Christopher H. Achen, and Thomas König, 86-123. Cambridge: Cambridge University Press.

Allison, Paul David. 2001. Missing Data. SAGE.

Baron, David P, and John A Ferejohn. 1989. "Bargaining in Legislatures." American Political Science Review 83 (4, December): 1181-1206.

Benedetto, Giacomo. 2005. "Rapporteurs as Legislative Entrepreneurs: The Dynamics of the Codecision Procedure in Europe's Parliament." Journal of European Public Policy 12 (1): 67-88.

Börzel, Tanja A. 2001. "Non-compliance in the European Union: Pathology or Statistical Artefact?" Journal of European Public Policy 8 (5, October): 803-824.

Cameron, Charles M. 2000. Veto Bargaining: Presidents and the Politics of Negative Power. Cambridge: Cambridge University Press.

Costello, Rory, and Robert Thomson. 2011. "The Nexus of Bicameralism: Rapporteurs' Impact on Decision Outcomes in the European Union." European Union Politics 12 (3) (September 1): 337-357. doi:10.1177/1465116511410087.

Crombez, Christophe. 1997. "The Co-Decision Procedure in the European Union." Legislative Studies Quarterly 22 (1): 97-119.

— 2001. "The Treaty of Amsterdam and the Co-decision Procedure." In The Rules of Integration: Institutional Approaches to the Study of Europe, ed. Gerald Schneider and Mark Aspinwall. Manchester: Manchester University Press.

Dixit, Avinash, and Susan Skeath. 1999. Games of Strategy. London: W.W. Norton \& Company.

Epstein, David, and Sharyn O'Halloran. 1999. Delegating Powers: A Transaction Cost Politics Approach to Policy Making Under Separate Powers. Cambridge: Cambridge University Press.

European Parliament. 2009. Delegations to the Conciliation Committee: Activity Report 1 May 2004 to 30 April 2009. Bruxelles: European Parliament.

Farrell, Henry, and Adrienne Héritier. 2004. Inter-organizational Negotiation and Intraorganizational Power in Shared Decision-Making: Early Agreements Under Codecision and Their Impact on the European Parliament and the Council of Ministers. 95.

Franchino, Fabio. 2007. The Powers of the Union: Delegation in the EU. Cambridge: Cambridge University Press.

Gailmard, Sean, and Thomas Hammond. 2011. "Intercameral Bargaining and Intracameral Organization in Legislatures.” The Journal of Politics 73 (02) (May): 535-546. doi:10.1017/S0022381611000338.

Garrett, Geoffrey. 1995. "From the Luxembourg Compromise to Codecision: Decision Making in the European Union." Electoral Studies 14 (3): 289 - 308.

Garrett, Geoffrey, and George Tsebelis. 1996. "An Institutional Critique of Intergovernmentalism." International Organization 50 (2): 269-299.

Hagemann, Sara, and Bjørn Høyland. 2010. "Bicameral Politics in the European Union." Jcms-journal of Common Market Studies 48 (4) (September): 811-833. 
Hix, Simon. 2002. "Constitutional Agenda-Setting Through Discretion in Rule Interpretation: Why the European Parliament Won at Amsterdam." British Journal of Political Science 32 (2): 259-280.

Hosli, Madeleine O, Mikko Mattila, and Marc Uriot. 2011. "Voting in the Council of the European Union After the 2004 Enlargement: A Comparison of Old and New Member States.” JCMS: Journal of Common Market Studies 49 (6) (November 1): 1249-1270. doi:10.1111/j.1468-5965.2011.02196.x.

Huber, John D, and Charles R Shipan. 2002. Deliberate Discretion? The Institutional Foundations of Bureaucratic Autonomy. Cambridge: Cambridge University Press.

Ingberman, Daniel E., and Dennis A. Yao. 1991. "Presidential Commitment and the Veto." American Journal of Political Science 35 (2) (May 1): 357-389. doi:10.2307/2111367.

Kasack, Christiane. 2004. "The Legislative Impact of the European Parliament Under the Revised Co-Decision Procedure: Environmental, Public Health and Consumer Protection Policies." European Union Politics 5 (2): 241-260.

König, Thomas, Bjorn Lindberg, Sandra Lechner, and Winfried Pohlmeier. 2007. "Bicameral Conflict Resolution in the European Union: An Empirical Analysis of Conciliation Committee Bargains." British Journal of Political Science 37 (2): 281312.

Matthews, Steven A. 1989. "Veto Threats: Rhetoric in a Bargaining Game." The Quarterly Journal of Economics 104 (2) (May 1): 347-369. doi:10.2307/2937851.

McCarty, Nolan M. 1997. "Presidential Reputation and the Veto." Economics \& Politics 9 (1) (March 1): 1-26. doi:10.1111/1468-0343.00017.

McCarty, Nolan, and Adam Meirowitz. 2007. Political Game Theory. New York: Cambridge University Press.

Moravcsik, Andrew. 1999. "A New Statecraft? Supranational Entrepreneurs and International Cooperation.” International Organization 53 (2, Spring): 267-306.

Napel, Stefan, and Mika Widgrén. 2006. "The Inter-Institutional Distribution of Power in EU Codecision." Social Choice and Welfare 27 (1): 129-154.

Pollack, Mark A. 2003. The Engines of European Integration: Delegation, Agency, and Agenda Setting in the EU. Oxford: Oxford University Press.

Proksch, Sven-Oliver, and Jonathan B. Slapin. 2009. WORDFISH: Scaling Software for Estimating Political Positions from Texts. http://www.wordfish.org.

Rasmussen, Anne. 2003. "The Role of the European Commission in Co-decision - A Strategic Facilitator Operating in a Situation of Structural Disadvantage." European Integration Online Papers (EIoP) 7. http://ideas.repec.org/a/erp/eiopxx/p0102.html.

—. 2005. "EU Conciliation Delegates: Responsible or Runaway Agents?" West European Politics 28 (5): 1015-1034. doi:10.1080/01402380500310675.

—. 2008. "The EU Conciliation Committee: One or Several Principals?" European Union Politics 9 (1): 87-113.

Rittberger, Bethold. 2000. "Impatient Legislators and New Issue-Dimensions: A Critique of the Garrett-Tsebelis 'Standard Version' of Legislative Politics.” Journal of European Public Policy 7 (4): 554-575.

Rubinstein, Ariel. 1982. "Perfect Equilibrium in a Bargaining Model." Econometrica 50 (1) (January 1): 97-109. doi:10.2307/1912531.

Schelling, Thomas C. 1960. The Strategy of Conflict. Cambridge: Harvard University Press. 
Slapin, Jonathan B., and Sven-Oliver Proksch. 2008. "A Scaling Model for Estimating Time-Series Party Positions from Texts." American Journal of Political Science 52 (3) (July 1): 705-722.

Steunenberg, Bernard. 1994. "Decision Making Under Different Institutional Arrangements: Legislation by the European Community." Journal of Institutional and Theoretical Economics 150 (4): 642-669. . 1997. "Codecision and Its Reform: A Comparative Analysis of Decision Making Rules in the European Union." In Political Institutions and Public Policy: Perspective on European Decision-Making, ed. Bernard Steunenberg and Frans van Vught, 205-29. Dordrecht: Kluwer.

Thomson, Robert. 2011. Resolving Controversy in the European Union: Legislative Decision-Making Before and After Enlargement. 1st ed. Cambridge University Press.

Thomson, Robert, Frans N. Stokman, Christopher H. Achen, and Thomas König, eds. 2006. The European Union Decides. Cambridge: Cambridge University Press.

Tsebelis, George. 2002. Veto Players: How Political Institutions Work. Princeton: Princeton University Press.

Tsebelis, George, and Geoffrey Garrett. 2000. "Legislative Politics in the European Union." European Union Politics 1 (1, February): 9-36.

Tsebelis, George, Christian B Jensen, Anastassios Kalandrakis, and Amie Kreppel. 2001. "Legislative Procedures in the European Union: An Empirical Analysis." British Journal of Political Science 31: 573-599.

Tsebelis, George, and Jeanette Money. 1997. Bicameralism. Cambridge: Cambridge University Press. 